\title{
PEMBERIAN NUGGET LELE (Clarias Batrachus) PENCAMPURAN DENGAN DAUN KATUK (Sauropus Androgynous Merr.) FORTIFIKASI FE TERHADAP KADAR HEMOGLOBIN IBU HAMIL ANEMIA
}

\author{
Devillya Puspita Dewi*, Kuntari Astriana \\ Prodi Gizi Program Sarjana Fakultas Ilmu Kesehatan Universitas Respati Yogyakarta \\ Jalan Raya Tajem km 1,5 Maguwoharjo Depok Sleman Yogyakarta, Indonesia \\ *Korespondensi: deandra bram@yahoo.com,
}

\begin{abstract}
Background: Anemia in pregnant women can increase the risk of maternal and infant morbidity and mortality. Giving catfish nuggets with a mixture of katuk leaves is expected to overcome the incidence of anemia in pregnant women.

Objective: To determine the effect of giving catfish nuggets mixed with katuk leaf flour on nutritional status and hemoglobin $(\mathrm{Hb})$ levels in anemic pregnant women.

Methods: Quasi-experimental research design with pre-test post-test group design. The research sample was pregnant women with anemia, which amounted to 48 anemic pregnant women who were divided into the treatment group and the control group. Pregnant women with anemia were given catfish nuggets mixed with katuk leafflour as much as 100 grams per day for 21 days and iron tablets, while for the control group only iron tablets were given. Data analysis using independent t test.

Results: Based on statistical tests there was no difference in nutritional status in the treatment group and the control group $(p=0,293)$ and there was no difference in the mean Hb levels in the treatment group and the control group before the intervention $p=0.254$. There was a difference in the average Hb level after the intervention $(p<0.05)$. There was an average difference in hemoglobin levels before and after treatment in the treatment group $(p<0.001)$ but not in the control group ( $p$-value $=0.667)$.

Conclusion: Giving catfish nuggets mixed with katuk leaf flour and iron tablets can increase hemoglobin (Hb) levels in anemic pregnant women but not in the control group.
\end{abstract}

Keywords: Anemia; Pregnant women; Hb levels; Catfish nuggets

\section{ABSTRAK}

Latar belakang: Anemia pada ibu hamil dapat meningkatkan risiko kesakitan dan kematian ibu dan bayi. Pemberian nugget lele dengan pencampuran daun katuk diharapkan dapat menanggulangi kejadian anemia pada ibu hamil.

Tujuan: Mengetahui pengaruh pemberian nugget lele pencampuran tepung daun katuk terhadap status gizi dan kadar hemoglobin (Hb) pada ibu hamil anemia

Metode: Desain penelitian quasi experiment dengan rancangan pre test post test group design. Sampel penelitian adalah ibu hamil yang mengalami anemia yang berjumlah 48 ibu hamil anemia yang dibagi menjadi kelompok perlakuan dan kelompok kontrol. Ibu hamil anemia untuk kelompok perlakuan diberikan nugget lele pencampuran tepung daun katuk sebanyak 100 gram per hari selama 21 hari dan tablet Fe sedangkan untuk kelompok kontrol hanya diberikan tablet Fe saja. Analisis data menggunakan independent t test.

Hasil: Berdasarkan uji statistik tidak apa perbedaan status gizi pada kelompok perlakuan dan kelompok kontrol $(p=0,293)$ serta tidak ada perbedaan rerata kadar Hb pada kelompok perlakuan dan kelompok kontrol sebelum intervensi $p=0,254$. Ada perbedaan rerata kadar Hb sesudah intervensi $(p<0,05)$. Ada perbedaan rerata kadar $\mathrm{Hb}$ sebelum dan sesudah perlakuan pada kelompok perlakuan $(p<0,001)$ namun tidak pada kelompok kontrol ( $p$ value=0,677).

Simpulan: Pemberian nugget lele pencampuran tepung daun katuk dan tablet Fe dapat meningkatkan kadar hemoglobin $(\mathrm{Hb})$ pada ibu hamil anemia tetapi tidak pada kelompok kontrol

Kata Kunci: Anemia; Ibu hamil; Kadar Hb; Nugget lele 


\section{PENDAHULUAN}

Anemia adalah suatu kondisi dimana tubuh mempunyai kadar sel darah merah (eritrosit) yang kurang dari normal, dimana didalam sel darah merah terkandung hemoglobin yang berfungsi untuk membawa oksigen ke seluruh jaringan tubuh. ${ }^{1}$ Kelompok yang mempunyai resiko anemia diantaranya adalah ibu hamil. Lebih dari setengah penduduk dunia yaitu anak belum sekolah dan ibu hamil mengalami anemia. Anemia defisiensi besi merupakan tahap defisiensi besi. World Health Organization (WHO) pada tahun 2014 menyatakan kejadian anemia terjadi pada 1,62 juta orang di dunia. WHO melaporkan bahwa terdapat $52 \%$ ibu hamil mengalami anemia di negara berkembang. Prevalensi anemia secara nasional tahun 2013 sebesar 37,1\%. Di Indonesia prevalensi anemia pada ibu hamil mengalami peningkatan pada tahun 2018 yaitu 40,1\%, salah satunya termasuk Daerah Istimewa Yogyakarta dengan prevalensi sebesar $15 \% .^{2}$

Beberapa studi menyebutkan bahwa anemia pada kehamilan merupakan penyebab tidak langsung pada kematian ibu hamil di negara berkembang sebesar $23,0 \%$. Perdarahan yang hebat saat ibu melahirkan dapat menimbulkan komplikasi pada ibu hamil dengan anemia. ${ }^{3}$ Penyebab tingginya prevalensi anemia pada ibu hamil yaitu kebutuhan zat besi yang meningkat akibat perubahan fisiologis dan metabolisme pada ibu, inadequate intake (utamanya zat besi, dan juga defisiensi asam folat dan vitamin B12), gangguan penyerapan, infeksi (malaria dan kecacingan), kehamilan yang berulang, thalasemia dan sickle cell disease, kondisi sosial, ekonomi, budaya dan pendidikan ibu. Anemia sebagian besar disebabkan oleh asupan zat besi dari makanan yang kurang. Anemia pada ibu hamil dapat meningkatkan risiko kesakitan dan kematian pada ibu dan bayi. ${ }^{4}$

Upaya penanggulangan anemia sudah banyak dilakukan dengan meningkatkan asupan zat besi dari makanan. Oleh karena itu anemia menjadi sasaran perbaikan gizi masyarakat yaitu dengan pemberian suplementasi besi. Upaya penanggulangan anemia di Indonesia memiliki tiga strategi yaitu suplemetasi besi, pendidikan gizi dan fortifikasi pangan. Program yang dilakukan pemerintah adalah Pencegahan dan Penanggulangan Anemia Gizi Besi (PPAGB) dengan target ibu hamil. Meskipun program tersebut sudah dilakukan oleh pemerintah tetapi dapat dilihat bahwa angka kejadian anemia pada ibu hamil masih tinggi. ${ }^{2}$

Salah satu cara untuk menanggulangi anemia pada ibu hamil adalah dengan diversifikasi pangan. Diversifikasi pangan dengan mengolah ikan menjadi nugget. Nugget adalah salah satu produk olahan setengah jadi makanan yang berasal dari daging giling atau produk hewani dengan campuran bumbu dan merupakan produk emulsi. ${ }^{4}$

Ikan yang digunakan dalam penelitian ini adalah lele yang mempunyai kandungan gizi setiap 100 gram yaitu protein $17,7 \mathrm{~g}$, lemak 4,8 g, mineral 1,2 g dan karbohidrat 0,3 g. ${ }^{5}$ Penganekaragaman dalam pengolahan ikan lele diharapkan dapat memberikan beberapa keuntungan seperti peningkatan mutu nilai gizi, daya tahan, dan zat gizi hasil olah nugget. ${ }^{6}$ Bahan makanan yang lain yang mempunyai kandungan zat besi tinggi adalah daun katuk. Daun katuk telah dikenal luas oleh masyarakat sebagai sayur, di samping daun katuk memiliki efek laktagogum (pelancar ASI), daun katuk juga memiliki kandungan kalsium $185 \mathrm{mg}$, zat besi 3,1 mg dan mengandung serat 1,2 gram. ${ }^{7}$ Kadar zat besi pada daun katuk dapat menjadi alternatif untuk pengobatan anemia defisiensi besi. Diversifikasi pangan dengan pencampuran tepung daun katuk pada pembuatan nugget lele dapat menjadikan produk untuk pencegahan dan pengobatan anemia pada ibu hamil. Berdasarkan uraian tersebut penelitian bertujuan untuk mengetahui pengaruh pemberian nugget lele pencampuran tepung daun katuk terhadap status gizi dan kadar hemoglobin $\mathrm{(Hb)}$ pada ibu hamil anemia.

\section{METODE}

Penelitian ini menggunakan quasi experimental dengan rancangan pretest posttest group design yaitu dengan memberikan intervensi kepada subjek penelitian berupa pemberian nugget lele dengan pencampuran tepung daun katuk dan pemberian tablet $\mathrm{Fe}$ untuk kelompok perlakuan serta pemberian tablet Fe saja untuk kelompok kontrol sedangkan untuk kadar $\mathrm{Hb}$ pada ibu hamil diukur sebelum intervensi dan sesudah intervensi. Nugget lele pencampuran tepung daun katuk diberikan selama 21 hari serta tablet $\mathrm{Fe}$ dikonsumsi 1 butir setiap hari. Penelitian ini dilakukan pada bulan Juli-Oktober 2019 dan telah mendapatkan surat ethical clearance dari Komisi Etik Fakultas Ilmu Kesehatan Universitas Respati Yogyakarta dengan nomor 184.3/FIKES/PL/VII/2019. Pembuatan tepung daun katuk dan pembuatan nugget dilakukan di Laboratorium Teknologi Pangan Universitas Respati Yogyakarta. Pemeriksaan kadar $\mathrm{Hb}$ dilakukan di Puskesmas Gedangsari II dilakukan oleh tenaga analis kesehatan, sedangkan untuk pemeriksaan status gizi ibu hamil menggunakan 
LILA yang dilakukan oleh peneliti dibantu oleh dengan enumerator terlatih dengan latar belakang pendidikan S1 Gizi yang telah dilatih sebelumnya.

Subjek dalam penelitian ini adalah ibu hamil di wilayah kerja Puskesmas Gedangsari Kabupaten Gunung Kidul, Yogyakarta dengan mempunyai kriteria yaitu ibu hamil menderita anemia dan tidak menderita penyakit infeksi dan penyakit kronis, serta bersedia mengisi informed consent sebagai bentuk kesediaan dan kesepakatan antara subjek dan peneliti sampai akhir penelitian. Kriteria eksklusinya adalah ibu hamil dengan penyakit jantung bawaan, . Besar sampel dalam penelitian ini ditentukan dengan metode Issac dan Michael untuk tingkat kesalahan
$5 \%$ dan $10 \%{ }^{8}$. Jumlah sampel penelitian sebanyak 24 ibu hamil anemia pada setiap kelompok. Sampel pada kelompok perlakuan menerima nugget lele pencampuran tepung daun katuk selama 1 x 100 gram per hari selama 21 hari dan tablet $\mathrm{Fe}$ sedangkan kelompok kontrol hanya mengkonsumsi tablet Fe kemudian diukur kadar $\mathrm{Hb}$ nya. Komposisi gizi nugget lele pencampuran tepung daun katuk seperti dalam Tabel 1. Pemantauan konsumsi nugget peneliti dibantu oleh petugas gizi Puskesmas untuk mengontrol konsumsi nugget lele pencampuran tepung daun katuk.

Tabel 1 Kandungan Gizi Nugget Lele Pencampuran Tepung Daun Katuk

\begin{tabular}{lc}
\hline \multicolumn{1}{c}{ Jenis zat gizi } & Konsentrasi (\%) \\
\hline Kadar Air & 50,21 \\
Kadar Abu & 1,37 \\
Kadar Lemak & 10,13 \\
Kadar Protein & 12,77 \\
Kadar Karbohidrat & 19,26 \\
Kadar Fe (mg) & 78,08 \\
\hline
\end{tabular}

Variabel bebas dalam penelitian ini adalah pemberian nugget lele pencampuran tepung daun katuk dan untuk variabel terikatnya adalah kadar $\mathrm{Hb}$ ibu hamil sehingga peneliti melihat pengaruh pemberian nugget lele pencampuran tepung daun katuk terhadap kadar $\mathrm{Hb}$ ibu hamil anemia. Sebelum penelitian dilakukan, pengambilan data dimulai dengan menjelaskan garis besar penelitian dan meminta subjek untuk menandatangani informed consent. Sebelum intervensi dimulai terlebih dahulu dilakukan pengukuran kadar $\mathrm{Hb}$. Setelah itu kemudian dilanjutkan dengan intervensi selama 21 hari. Kadar $\mathrm{Hb}$ dikumpulkan dengan metode Finger Test Stick menggunakan Easy Touch Strip Hemoglobin, sejalan dengan penelitian yang mengatakan bahwa metode finger test stik dianggap penduga yang berguna untuk melihat Kadar $\mathrm{Hb}$. Pretest dilakukan untuk mengetahui kadar $\mathrm{Hb}$ ibu hamil anemia sebelum intervensi, kadar $\mathrm{Hb}$ ibu hamil anemia adalah kurang dari 11 $\mathrm{g} / \mathrm{dL}$. Setelah diberikan intervensi selama 21 hari kemudian dilakukan post test yaitu pengukuran kadar $\mathrm{Hb}$ ibu hamil yang diberikan intervensi.

Analisis data menggunakan analisis statistik yang dilakukan dengan perangkat lunak SPSS. Variabel yang termasuk dalam penelitian ini adalah kadar $\mathrm{Hb}$ dan status gizi. Pengaruh pemberian nugget lele pencampuran tepung daun katuk dianalisis menggunakan uji-t berpasangan sedangkan perbedaan konsentrasi hemoglobin dan status gizi antar kelompok menggunakan $u j i-$ $t$ tidak berpasangan dikarenakan data terdistribusi normal setelah di analisis dengan menggunakan uji Kolmogorov-Smirnov.

\section{HASIL}

\section{Karakteristik Responden}

Data ibu hamil anemia diperoleh dengan melakukan skrining ibu hamil di Puskesmas Gedangsari I dan II diperoleh 58 ibu hamil anemia dari total $134 \mathrm{ibu}$ hamil. Kemudian diambil $58 \mathrm{ibu}$ hamil untuk dijadikan sampel penelitian dan terdapat $10 \mathrm{ibu}$ hamil yang tidak memenuhi kriteria inklusi sehingga tersisa 48 ibu hamil anemia. Dari 48 ibu hamil anemia kemudian dilakukan randomisasi untuk menentukan kelompok perlakuan yang diberikan nugget lele pencampuran tepung daun katuk dan tablet $\mathrm{Fe}$ dan kelompok kontrol hanya mengkonsumsi tablet $\mathrm{Fe}$ saja. Dari data karakteristik responden pada Tabel 2 dapat dilihat bahwa pada kelompok perlakuan sebagian besar berumur 21-35 tahun sebanyak 18 (75\%), mempunyai riwayat multipara $21(87,5 \%)$, tidak bekerja $22(91,7 \%)$, pendidikan rendah 14 $(58,3 \%)$ dan status gizi normal 19(79,2\%). Sedangkan pada kelompok kontrol dapat dilihat berumur 21-35 tahun sebanyak $21 \quad(87,5 \%)$, mempunyai riwayat multipara $20(83,3 \%)$, tidak bekerja $22(91,7 \%)$, pendidikan tinggi $15(62,5 \%)$ dan status gizi normal $21(87,5 \%)$. 
Tabel 2. Karakteristik Subjek Penelitian

\begin{tabular}{|c|c|c|c|c|c|}
\hline \multirow{2}{*}{ Karakteristik } & \multicolumn{2}{|c|}{ Perlakuan $(n=24)$} & \multicolumn{2}{|c|}{ Kontrol $(n=24)$} & \multirow[t]{2}{*}{$p$ value } \\
\hline & $\mathrm{n}$ & $\%$ & $\mathrm{n}$ & $\%$ & \\
\hline \multicolumn{6}{|l|}{ Umur (tahun) } \\
\hline$<21$ tahun dan $>35$ tahun & 6 & 25 & 3 & 12,5 & \multirow[t]{2}{*}{$0,875^{*}$} \\
\hline $21-35$ tahun & 18 & 75 & 21 & 87,5 & \\
\hline \multicolumn{6}{|l|}{ Paritas } \\
\hline Primipara & 3 & 12,5 & 4 & 16,7 & \multirow[t]{2}{*}{$0,653^{*}$} \\
\hline Multipara & 21 & 87,5 & 20 & 83,3 & \\
\hline \multicolumn{6}{|l|}{ Pekerjaan } \\
\hline Bekerja & 2 & 8,3 & 2 & 8,3 & \multirow[t]{2}{*}{$0,337^{*}$} \\
\hline Tidak bekerja & 22 & 91,7 & 22 & 91,7 & \\
\hline \multicolumn{6}{|l|}{ Pendidikan } \\
\hline Rendah & 14 & 58,3 & 9 & 37,5 & \multirow[t]{2}{*}{$0,266^{*}$} \\
\hline Tinggi & 10 & 41,7 & 15 & 62,5 & \\
\hline \multicolumn{6}{|l|}{ Status Gizi } \\
\hline Normal & 19 & 79,2 & 21 & 87,5 & \multirow[t]{2}{*}{$0,293^{*}$} \\
\hline KEK & 5 & 20,8 & 3 & 12,5 & \\
\hline
\end{tabular}

Tabel 3. Kadar Hb dan status gizi bu hamil sebelum dan sesudah intervensi

\begin{tabular}{lccc}
\hline \multicolumn{1}{c}{ Variabel } & Perlakuan $($ rerata \pm SD) & Kontrol (rerata \pm SD) & $\boldsymbol{p}$ value \\
\hline Kadar Hemoglobin & & & \\
Sebelum (g/dl) & $8,79 \pm 0,78$ & $9,59 \pm 0,92$ & 0,254 \\
Sesudah (g/dl) & $12,20 \pm 1,08$ & $10,87 \pm 0,82$ & $<0,001^{*}$ \\
$\Delta$ Sebelum-Sesudah & $3,42 \pm 0,98$ & $10,93 \pm 0,93$ & \\
$p$ value & $<0,001^{*}$ & 0,667 & \\
Status Gizi (LILA) & & & \\
Sebelum (cm) & $22,16 \pm 0,98$ & $22,59 \pm 0,73$ & 0,146 \\
Sesudah $(\mathrm{cm})$ & $23,17 \pm 0,78$ & $23,04 \pm 0,87$ & 0,214 \\
$\Delta$ Sebelum-Sesudah & $1,76 \pm 0,73$ & $1,59 \pm 0,81$ & \\
$p$ value & 0,166 & 0,203 & \\
\hline
\end{tabular}

Subjek penelitian dilakukan pengukuran kadar Hemoglobin dan status gizi (LILA) sebelum dan setelah diberikan perlakukan yaitu kelompok perlakukan diberikan nugget lele pencampuran tepung daun katuk dan tablet Fe dan kelompok kontrol hanya mengkonsumsi tablet Fe saja. Data kadar hemoglobin dan status gizi dapat dilihat pada Tabel 3 dibawah. Hasil dari kelompok perlakuan dapat dilihat bahwa kadar hemoglobin sebelum diberikan nugget dan tablet $\mathrm{Fe}$ mempunyai rerata $8,79 \pm 0,78 \mathrm{~g} / \mathrm{dL}$ dan sesudah diberikan nugget dan tablet Fe mempunyai rerata $12,20 \pm 1,08 \mathrm{~g} / \mathrm{dL}$. Artinya pemberian nugget dan tablet Fe dapat meningkatkan kadar hemoglobin secara signifikan $(p<0,05)$. Sedangkan pada kelompok kontrol yang hanya diberikan tablet $\mathrm{Fe}$ saja kadar hemoglobin sebelum mempunyai rerata 9,59 $\pm 0,92 \mathrm{~g} / \mathrm{dL}$ dan kadar hemoglobin sesudah mempunyai rerata $10,87 \pm 0,82 \mathrm{~g} / \mathrm{dL}$ artinya kadar hemoglobin mengalami peningkatatn tetapi tidak signifikan $(p>0,05)$. Berdasarkan uji statistik menggunakan uji $t$ diperoleh bahwa tidak ada perbedaan kadar hemoglobin sebelum pada intervensi pada kelompok perlakuan dan kelompok kontrol $(p=0,254)$. Ada perbedaan nyata sesudah intervensi antara kelompok perlkaukan dan kelompok kontrol $(p<0,001)$.

Data status gizi (LILA) pada kelompok perlakuan sebelum diberikan intervensi mempunyai rerata $22,16 \pm 0,98 \mathrm{~g} / \mathrm{dL}$ dan sesudah diberikan intervensi mempunyai rerata $23,17 \pm 0,78 \mathrm{~g} / \mathrm{dL}$ artinya status gizi mengalami peningkatan tetapi berdasarkan uji statistik tidak signifikan $p=0,166$.

\section{PEMBAHASAN}

Penelitian ini dilakukan untuk melihat pengaruh pemberian nugget lele pencampuran tepung daun katuk terhadap kadar hemoglobin ibu hamil. Karakteristik subjek penelitian dilihat dari umur, paritas, pekerjaan, pendidikan dan status gizi menunjukkan bahwa kedua kelompok mempunyai data awal yang sama dapat dilihat pada Tabel 2. Hal ini dapat dilihat bahwa pada karakteristik responden menunjukkan nilai $p>0,05$. Karakteristik umur merupakan faktor resiko terhadap kejadian anemia selama kehamilan. Umur ibu berkaitan dengan tingkat kematangan organ reproduksi. Umur reproduksi dengan tingkat kematangan yang aman adalah 
umur 20-35 tahun sedangkan usia kurang dari 20 tahun dan diatas 35 tahun adalah usia dengan tingkat resiko tinggi terhadap anemia. Karena pada usia kurang dari 20 tahun secara biologis belum matang tingkat emosinya masih labil, sehingga mudah mengalami gangguan yang mengakibatkan kurang perhatian terhadap pemenuhan kebutuhan gizi selama masa kehamilan. ${ }^{9}$ Hal ini tidak sesuai dengan penelitian seblumnya bahwa ada hubungan yang bermakna antara umur dengan kejadian anemia pada ibu hamil. ${ }^{10}$

Data awal dari subjek penelitian menunjukkan bahwa 48 subjek menderita anemia. Berdasarkan penelitian di dapat bahwa responden multipara lebih beresiko mengalami anemia dibandingkan dengan ibu hamil yang primipara. Ibu yang telah melahirkan lebih dari 3 kali berisiko mengalami komplikasi serius seperti perdarahan, hal ini dipengaruhi keadaan anemia selama kehamilan karena kehamilan menguras cadangan zat besi dalam tubuh. Wanita yang sering hamil mempunyai risiko mengalami anemia pada kehamilan berikutnya apabila tidak memperhatikan kebutuhan nutrisi. Seorang wanita yang hamil pertama kali juga dapat berisiko karena belum memiliki pengalaman. ${ }^{11}$ Ada hubungan yang bermakna antara paritas dengan kejadian anemia pada ibu hamil. ${ }^{10}$ Pendidikan ibu hamil sebagian besar berpendidikan rendah SD sampai SLTP ini yang menyebabkan pengetahuan mereka kurang pada ibu hamil. Mereka hanya mengetahui pengetahuan tentang gizi yang sedikit sehingga tidak maksimal dalam asupan gizi setiap harinya yang menyebabkan terjadinya anemia. ${ }^{12}$

Pemberian nugget pada kelompok perlakuan $100 \mathrm{gr} /$ hari dan pemberian tablet $\mathrm{Fe}$ selama 21 hari sedangkan pada kelompok kontrol hanya mengkonsumsi tablet $\mathrm{Fe}$ saja. Artinya pemberian nugget dan tablet $\mathrm{Fe}$ dapat meningkatkan kadar hemoglobin secara signifikan $(p<0,05)$. Sedangkan pada kelompok kontrol yang hanya diberikan tablet Fe saja kadar hemoglobin mengalami peningkatan tetapi tidak signifikan $(p>0,05)$. Kadar $\mathrm{Hb}$ merupakan salah satu indikator status anemia secara biokimiawi. Pemberian daun katuk dapat meningkatkan kadar $\mathrm{Hb} .^{7}$ Nugget lele pencampuran tepung daun katuk yang diberikan mempunyai kadar protein dan zat besi sebanyak $12,77 \%$ dan $78,08 \mathrm{mg} .{ }^{13}$ Pemberian nugget lele pencampuran tepung daun katuk sejalan dengan program pemerintah dalam penaggulangan anemia menggunakan diversifikasi pangan. Peningkatan kadar $\mathrm{Hb}$ ibu hamil tidak hanya dipengaruhi oleh konsumsi tablet besi saja tetapi juga didukung oleh asupan makanan sumber protein dan zat besi. Lele merupakan salah satu protein heme dari hewani sehingga akan terjadi interaksi heme dan globin sehingga membentuk hemoglobin.14 Nugget lele dengan pencampuran tepung daun katuk mempunyai kandungan protein dan fe yang tinggi yaitu $12,77 \%$ dan 78,08 mg. Apabila dikonsumsi dengan tablet $\mathrm{Fe}$ maka proses penyerapan di dalam tubuh menjadi maksimal. Pemberian tablet Fe bersamaan dengan konsumsi makanan sumber protein pada manusia lebih efektif karena sesuai dengan siklus pembaharuan sel-sel mukosa usus. ${ }^{15}$

Proses sintesis hemoglobin normal memerlukan cadangan zat besi yang mencukupi serta produksi protoporphyrin dan globin yang normal. Proses sintesis pada protoporphyrin dimulai di dalam mitokondria dengan pembentukan delta aminolevulenic acid (SALA) dari glisin, suksinil-CoA dan vitamin B6. Kemudian pada proses pembentukan porphobilinogen, uroporphyrin dan coproporphyrin terjadi di dalam sitoplasma sel. Dua molekul $\delta$ ALA bergabung membentuk porphobilinogen yang mengandung satu rantai pyrrole. Melalui proses deaminasi, empat prophobilinogen digabungkan menjadi hydroxymethylbilane, yang kemudian dihidrolisis menjadi uroporphyrin. Uroporphyrin kemudian mengalami dekarboksilasi menjadi coporphyrin. Enzimcoporphyrin oxidase mengoksidasi coporphyrinke pada protpoporphyrinogen. Protoporphyrinogen seterusnya dioksidasikan membentuk protoporphyrin. Protoporphyrin kemudian bergabung dengan ion $\mathrm{Fe}$ dengan bantuan enzim ferrokelase membentuk heme. ${ }^{14}$ Nugget lele dengan protein tinggi dan pemberian tablet $\mathrm{Fe}$ membantu proses sintesis hemoglobin pada ibu hamil.

Zat besi berkaitan dengan kadar hemoglobin ibu hamil karena zat besi merupakan mikro mineral yang esensial bagi tubuh. Zat besi diperlukan dalam hemopoboesis (pembentukan darah) yaitu sintesis hemoglobin $(\mathrm{Hb})$ yaitu suatu oksigen yang mengantarkan eritrosit berfungsi penting bagi tubuh. hemoglobin terdiri dari Fe (zat besi), protoporfirin, dan globin $(1 / 3$ berat $\mathrm{Hb}$ terdiri dari $\mathrm{Fe}$ ). ${ }^{15}$ Untuk meningkatkan kadar $\mathrm{Hb}$ pada ibu hamil tidak hanya dilakukan dengan pemberian tablet $\mathrm{Fe}$ tetapi dapat juga menggunakan intervensi makanan sumber protein dan Fe. Asupan jenis makanan dan pemberian suplemen zat besi pada ibu hamil berpengaruh terhadap kadar Hemoglobin. ${ }^{16}$ Ada efek pemberian suplementasi pada ketiga kelompok terhadap peningkatan kadar $\mathrm{Hb}$ pada remaja putri, namun kelompok tablet $\mathrm{Fe}+\mathrm{jus}$ jambu biji 
memiliki peningkatan kadar $\mathrm{Hb}$ yang lebih tinggi dan lebih cepat meningkatkan kadar $\mathrm{Hb}$ dibandingkan kelompok lain. ${ }^{17}$

Faktor-faktor yang meningkatkan kadar $\mathrm{Hb}$ ibu hamil seperti buah yang mengandung vitamin $\mathrm{C}$, Vitamin $\mathrm{B}$, serta makanan mengandung zat gizi dan protein tinggi. Asam askorbat (vitamin C), Asam Folat dan Protein merupakan faktor utama yang mendorong penyerapan zat besi nonheme. Vitamin C meningkatkan penyerapan zat besi nonhem sampai empat kali lipat. Bahan-bahan seperti sitrat, malat, laktat, suksinat, dan asam tartat dapat meningkatkan penyerapan zat besi nonhem pada kondisi tertentu. Vitamin $\mathrm{C}$ memiliki faktor reduksi yang bermanfaat meningkatkan absorpsi besi dengan mereduksi besi ferri menjadi ferro sehingga absorpsi besi menjadi efisien dan efektif. ${ }^{18}$ Responden mempunyai pola makan yang tidak baik karena konsumsi makanan yang kurang bervariasi dan makan tidak teratur.

Selama kehamilan akan terjadi peningkatan volume darah $35-45 \%$ dibandingkan dengan konsisi tidak hamil. ${ }^{19}$ Di samping itu dengan adanya pemberian intervensi dengan pemberian pangan yang terfortifikasi mampu mempertahankan kadar $\mathrm{Hb}$ dalam darah. Selain zat-zat yang dapat membantu penyerapan zat besi, Anemia juga di pengaruhi oleh zat-zat yang dapat menghambat penyerapan $\mathrm{Fe}$ yaitu fitat (katul, kedelai, jagung, coklat, susu dan kacangkacangan), polifenol (tanin) pada teh, bayam, kopi, kacang kacangan, kalsium (susu, keju), phospat (susu, keju). Penelitian sebelumnya menyatakan bahwa intervensi dengan crackers tinggi protein dan besi dapat meningkatkan kadar $\mathrm{Hb} 0,53 \mathrm{~g} / \mathrm{dl} .{ }^{16}$ Pemberian intervensi pengan fortifikasi berpengaruh terhadap anemia ibu hamil. ${ }^{19}$

\section{SIMPULAN}

Pemberian nugget lele pencampuran tepung daun katuk dan tablet $\mathrm{Fe}$ dapat meningkatkan kadar hemoglobin $(\mathrm{Hb})$ pada ibu hamil anemia tetapi tidak pada kelompok kontrol. Saran penelitian ini adalah ibu hamil sebaiknya dalam mengkonsumsi nugget lele atau sumber protein hewani yang lain disertai dengan konsumsi tablet $\mathrm{Fe}$ secara rutin.

\section{UCAPAN TERIMAKASIH}

Kami ucapkan terimakasih kepada Hibah PPPM Universitas Respati Yogyakarta yang sudah memberikan dana hibah Penelitian Dosen tahun 2020 .

\section{DAFTAR PUSTAKA}

1. Proverawati, A. Anemia dan Anemia Kehamilan. Nuha Medika, Yogyakarta. 2013.

2. Riskesdas. Laporan hasil Riset Kesehatan Dasar (Riskesdas) tahun 2013. Jakarta: Badan Penelitian dan Pengembangan Kesehatan Kementerian Kesehatan RI; 2013.

3. Ozdmir N. Iron deficiency anemia from diagnosis to treatment in children. Türk Pediatri Arşivi. 2015;50(1):11-9. https://doi.org/10.5152/tpa.2015.2337

4. Pertiwi AP, Mardesci H. Studi tentang penambahan kangkung darat (ipomeareptanspoir) terhadap kualitas kimia nugget ikan lele (Clarias gariepinus). Jurnal Teknologi Pertanian. 2016; 5(2):41-46. https://doi.org/10.32520/jtp.v5i2.94

5. Suyanto SR. Budidaya Ikan Lele. Penebar Swadaya. Jakarta. 2007.

6. Wellyalina, Azima F, Aisman. Pengaruh perbandingan tetelan merah tuna dan tepung maizena terhadap mutu nugget. Jurnal Aplikasi Teknologi Pangan. 2013;2(1):6-17.

7. Andari A. Uji Aktifitas ekstrak daun katuk (sauropus androgynus 1. merr) sebagai antioksidan pada minyak kelapa. Skripsi Program Studi Kimia Universitas Islam Negeri Yogyakarta. Skripsi. 2013.

8. Kasim VN, Pateda SM, Hadju V, Jafar N. Suplementasi ekstrak albumin ikan gabus terhadap status gizi dan imunitas pasien stroke. Jurnal Gizi Klinik Indonesia. 2017;13(3): 91-98. https://doi.org/10.22146/ijen.21964

9. Amirudin dan Wahyuddin. Studi kasus kontrol faktor biomedis terhadap kejadian anemia ibu hamil di puskesmas Bantimurung Maros. Jurnal Medika Nusantara. 2014;25(2):123-130.

10. Astriana W. Kejadian anemia pada ibu hamil ditinjau dari paritas dan usia. Jurnal Ilmu Kesehatan 2017;2(2):123-130. https://doi.org/ 10.30604/jika.v2i2.57

11. Subekti R, Sulistyorini D. Analisis faktor risiko penyebab anemia pada ibu hamil di puskesmas wilayah kabupaten Banjarnegara Tahun 2018. Medsains. 2018;4(1):34-39.

12. Purwaningrum Y. Pengetahuan ibu hamil tentang gizi dengan kejadian anemia selama kehamilan. Jurnal Kesehatan. 2019;5(2):8893. https://doi.org/10.25047/j-kes.v5i2.52

13. Nefri, Sukmiwati M, Sumarto. Pengaruh penambahan tepung daun katuk (sauropus androgynus) terhadap mutu nugget ikan lele (Clarias batracus). Naskah Publikasi Universitas Riau. 2018. 
14. Uluwiyatun U, Runjati R, Suwondo A. Pengaruh konsumsi rumput laut (eucheuma sp) terhadap peningkatan kadar hemoglobin dan status Fe ibu hamil anemia di kabupaten Pekalongan. Jurnal Kebidanan. 2014;3(7):815. https://doi.org/10.31983/jkb.v3i7.117

15. Marizal. Anemia defisiensi besi. Kesehatan Masyarakat. 2007;2(1):114. https://doi.org/10.24893/jkma.v2i1.23

16. Rimawati E, Kusumawati E, Gamelia E, Sumarah, Nugraheni SA. Intervensi suplemen makanan untuk meningkatkan kadar $\mathrm{Hb}$ pada ibu hamil. Jurnal Ilmu Kesehatan Masyarakat. 2018;9(3):161-170. https://doi.org/10.26553/jikm.2018.9.3.161$\underline{170}$
17. Andaruni NQR, Nurbaety BQ. Efektivitas Pemberian tablet zat besi (Fe), vitamin $\mathrm{C}$ dan jus buah jambu biji terhadap peningkatan kadar $\mathrm{Hb}$ remaja putri di Universitas Muhammadiyah Mataram. Midwifery Journal. 2018;3(2):104-107. https://doi.org/10.31764/mj.v3i2.509

18. Ristica OD. Faktor risiko kejadian anemia pada ibu hamil. Jurnal Kesehatan Komunitas 2013;2(2):78-82.

19. Prihananto V, Rimbawan, Astawan M, Sulaeman A, Sandjaja. Pengaruh pemberian pangan yang difortifikasi terhadap peningkatan konsumsi gizi dan status anemia ibu hamil. Jurnal Pembangunan Pedesaan. 2006;6(3):192-200. 